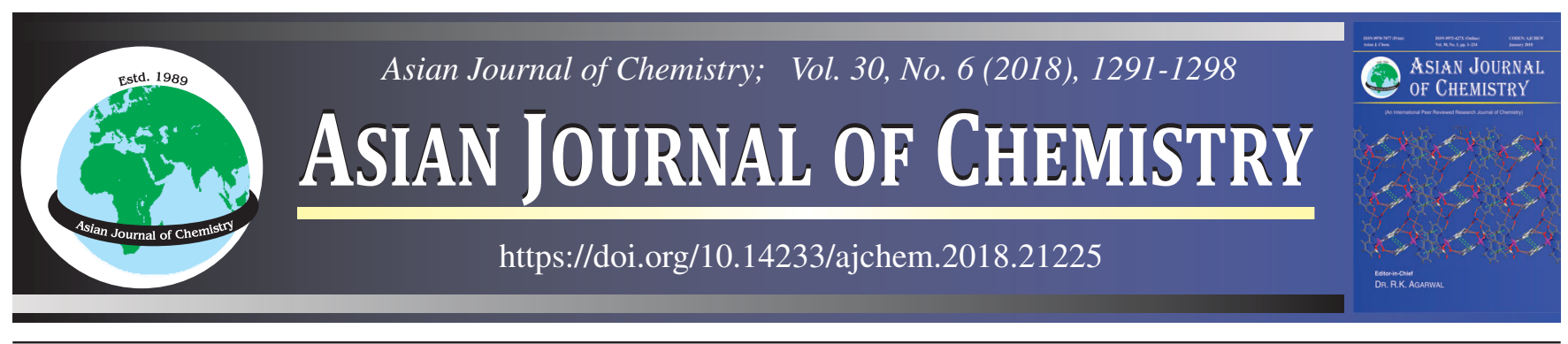

\title{
Quantum Mechanical Calculations for Reaction Path of \\ O-R Bond Breakage in Some of Cefpodoxime Prodrugs
}

\author{
R.M. KuBBA
}

Department of Chemistry, College of Science, University of Baghdad, Jadiriya, Baghdad, Iraq

Corresponding author: Tel: +964 7700298442; E-mail: rehab_mmr_kb@yahoo.com

Received: 13 January 2018;

Accepted: 18 April 2018;

Published online: 30 April 2018;

AJC-18882

This work is Unrestricted Hartree Fock (UHF) quantum mechanical calculations of proton transfer and reaction path of (O-R) bond rupture energies in nine cefpodoxime prodrug derivatives of different substituted organic groups, at their optimize geometries. The calculation included geometrical structure, some of physical properties such as standard heat of formation, dipole moment and total energies, using Gaussian-09 program. Comparison was done between the total energies of the reactants, activation energies, transition states and end products. All the calculations are reported in the vacuum phase. The results showed that some of the substituted organic groups can be used as carrier linkages for the acidic cefpodoxime drug.

Keywords: Cefpodoxime proxetil ester derivatives, $\mathrm{O}-\mathrm{R}$ bond rupture.

ᄂ - - - - - - - - - - - - - -

\section{INTRODUCTION}

The term 'prodrug' was first introduced by Albert [1] to describe any compound that undergoes biotransformation prior to the exhibition of its pharmacological effect. It is signifies a pharmacologically inactive chemical derivative that could be used to alter the physico-chemical properties of drugs in a temporary manner to increase their usefulness and/or to decrease associated toxicity. The term prodrug is also called as 'proagent', 'bioreversible derivative' or 'latentiated drug', but prodrug is the most commonly accepted term [2]. Prodrug can be also defined as pharmacologically inert chemical derivatives that can be enzymatically or non-enzymatically converted in vivo to the active drug molecule to exert a therapeutic effect. According to IUPAC (International Union of Pure and Applied Chemistry): Prodrug is defined as any compound that undergoes biotransformation before exhibiting its pharmacological effects [3]. Depending upon the constitution, lipophilicity, method of deactivation and the catalyst involved in bio activation, prodrugs are classified into two categories i.e., carrier linked prodrug and bio precursor [4]. In recent years numerous prodrugs have been designed and developed to overcome barriers to drug utilization such as low oral absorption properties, lack of site specificity, chemical instability, toxicity, bad taste, bad odor and pain at application site [5,6]. Cefpodoxime proxetil (CPDP) $\left(\mathrm{R}=-\mathrm{CH}\left(\mathrm{CH}_{3}\right) \mathrm{OCOOCH}\left(\mathrm{CH}_{3}\right)_{2}\right)$ Fig. 1 , is chemically [6R$[6 \alpha, 7 \beta(\mathrm{z})]]-7-[[(2$-amino-4-thiozolyl)(methoxyimino)acetyl]amino]-3-(methoxymethyl)-8-oxo-5-this-1-azabicyclo[4.2.0]- oct-2-ene-2-carboxylic acid 1-[[(1-methyl ethoxy)carbonyl]oxy]ethyl ester. It is an oral third generation semi-synthetic cephalosporin and a $\beta$-lactam antibiotic used to treat a variety of bacterial infections. It is marketed as the prodrug cefpodoxime proxetil by Pharmacia and Upjohn under the trade names Vantin, Vercef. It is active against most Gram-positive and Gram-negative bacteria. Cefpodoxime is ideal to be used as a therapy in respiratory tract infections, it is poor water solubility also contributes to its low bioavailability $[1,7]$. Theoretically, Frau et al. [8] have calculated the optimize geometry of some penicillin's prodrugs using semiemperical calculations of MINDO/3, MINDO and AM1 methods. Karaman [9] studied proton transfer reactions for prodrugs of aza nucleosides molecules. Hejaz et al. [10] had revealed, that activation energy for the proton transfer in processes prodrugs, using DFT method is quite dependent on the transition state and geometric variations in the ground state. Kubba et al. had studied theoretically, using quantum mechanical calculations of semiemperical PM3 and (UHF) methods, the O-R bond rupture in some prodrugs derivatives of ampicillin and cefuroxime, including different substituted organic groups in an attempt to show which of them could be chosen as a good carrier linkage for ampicillin or cefuroxime medicinal [11-13].

The aim of the this research is to study the reaction path curves for the O-R bond rupture in some of new cefpodoxime linkages, by using ab initio Unrestricted Hartree Fock (UHF) method [14]. The study included the assignment of the energy of the reactant, activation energy, transition state and product, 


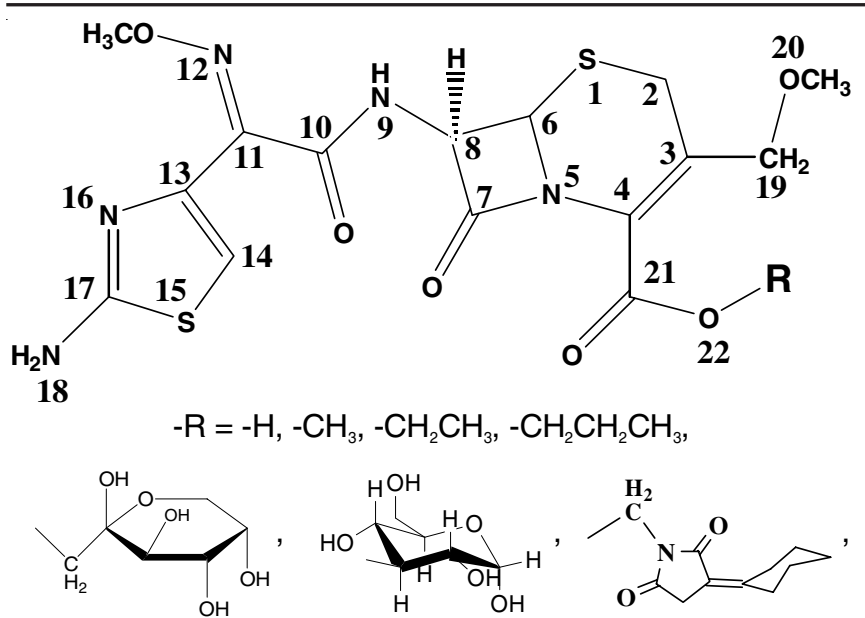

\section{$-\mathrm{CH}\left(\mathrm{CH}_{3}\right) \mathrm{OCOCH}\left(\mathrm{CH}_{3}\right)_{2},-\mathrm{CH}\left(\mathrm{CH}_{3}\right) \mathrm{OCOOCH}\left(\mathrm{CH}_{3}\right)_{2}$,} $-\mathrm{C}\left(\mathrm{CH}_{3}\right)_{2} \mathrm{OCOCH}\left(\mathrm{CH}_{3}\right)_{2},-\mathrm{C}\left(\mathrm{CH}_{3}\right)_{2} \mathrm{OCOCH}\left(\mathrm{CH}_{3}\right)_{2}$

Fig. 1. Structures and numbering of atoms of the calculated cefpodoxime acid $(-\mathrm{R}=-\mathrm{H})$ and ester-prodrug derivatives Pro. D (1-10) as applied in the present work

in addition to the nature and stability of the breakage end products. To out best of knowledge, there is no report of computational studies on proton transfer of $\mathrm{O}-\mathrm{R}$ bond rupture reaction for the cefpodoxime ester prodrugs, so these theoretical calculations provide a useful initial explanation for the data on cefpodoxime prodrugs in literature.

\section{COMPUTATIONAL METHODS}

All the quantum chemical calculations were performed with complete geometry optimizations using Gaussian-09 software package [15]. The geometry optimization was carried out for cefpodoxime acid and ten cefpodoxime ester prodrugs, Pro. D (1-10), Fig. 1, by ab initio open shell Unrestricted Hartree Fock (UHF/STO-3G) level [14]. The theoretical calculations were performed in the vacuum medium only for expecting (IPT) to be almost the same as in solution [16,17]. The optimization energy (for reactants or products compound) have no negative vibrational force constant [18].

\section{RESULTS AND DISCUSSION}

The UHF calculations of the structures (bond lengths $\AA$ ) for the calculated cefpodoxime acid $(\mathrm{R}=-\mathrm{H})$ and cefpodoximate derivatives Pro.D 1-10 at the equilibrium geometry are shown in Table-1. It was found that the difference for a specified bond was slightly shorter or slightly longer, referring to the convergence of their force constants. Extensive studies were concentrated on the bond length of O-R. This bond is linking drug with carrier. The values for O-R bond length of Pro. D (1-10) calculated by UHF/STO-3G were in the range of (1.434$1.448 \AA)$. The $\mathrm{O}-\mathrm{R}$ bond of shorter length was referred to the primary $\left(1^{\circ}\right)$ prodrug derivative (Pro. D4 $(\mathrm{R}=1$-Frectosyl)), while the longer $\mathrm{O}-\mathrm{R}$ bond length was belonged to the largest carrier linkage Pro. D5 ( $\mathrm{R}=-3$-Glycosyl). There is a presence

\begin{tabular}{|c|c|c|c|c|c|c|c|}
\hline \multirow[b]{3}{*}{$\begin{array}{c}\text { Bond } \\
\text { description }\end{array}$} & \multicolumn{6}{|c|}{$\begin{array}{l}\text { TABLE- } 1 \\
\text { UHF CALCULATIONS FOR THE BOND LENGTHS }(\AA) \text { OF CEFPODOXIME ACID }(\mathrm{R}=-\mathrm{H}) \text { AND } \\
\text { CEFPODOXIMATE DERIVATIVES AT THEIR EQUILIBRIUM GEOMETRIES }\end{array}$} & \\
\hline & \multicolumn{7}{|c|}{$-\mathrm{R}$} \\
\hline & $-\mathrm{H}$ & $-\mathrm{CH}_{3}$ & $-\mathrm{CH}_{2} \mathrm{CH}_{3}$ & $-\mathrm{CH}_{2} \mathrm{CH}_{2} \mathrm{CH}_{3}$ & & & \\
\hline $\mathrm{S} 1-\mathrm{C} 2$ & 1.804 & 1.803 & 1.805 & 1.804 & 1.804 & 1.802 & 1.805 \\
\hline S1-C6 & 1.803 & 1.803 & 1.803 & 1.803 & 1.804 & 1.803 & 1.803 \\
\hline $\mathrm{C} 2-\mathrm{C} 3$ & 1.534 & 1.533 & 1.534 & 1.534 & 1.534 & 1.534 & 1.533 \\
\hline $\mathrm{C} 3-\mathrm{C} 4$ & 1.327 & 1.325 & 1.325 & 1.326 & 1.325 & 1.328 & 1.325 \\
\hline C3-C19 & 1.531 & 1.532 & 1.531 & 1.531 & 1.533 & 1.533 & 1.537 \\
\hline C4-N5 & 1.438 & 1.440 & 1.439 & 1.440 & 1.436 & 1.438 & 1.439 \\
\hline N5-C6 & 1.486 & 1.486 & 1.486 & 1.485 & 1.484 & 1.486 & 1.490 \\
\hline $\mathrm{N} 5-\mathrm{C} 7$ & 1.448 & 1.449 & 1.448 & 1.449 & 1.446 & 1.448 & 1.452 \\
\hline C6-C8 & 1.569 & 1.572 & 1.572 & 1.572 & 1.566 & 1.564 & 1.565 \\
\hline C8-N9 & 1.459 & 1.456 & 1.456 & 1.455 & 1.463 & 1.464 & 1.462 \\
\hline N9-H & 1.023 & 1.022 & 1.022 & 1.022 & 1.030 & 1.030 & 1.029 \\
\hline N9-C10 & 1.429 & 1.427 & 1.427 & 1.426 & 1.430 & 1.434 & 1.434 \\
\hline $\mathrm{C} 10=\mathrm{O}$ & 1.220 & 1.220 & 1.220 & 1.220 & 1.219 & 1.219 & 1.220 \\
\hline $\mathrm{C} 10-\mathrm{C} 11$ & 1.536 & 1.536 & 1.536 & 1.537 & 1.543 & 1.545 & 1.542 \\
\hline C11-N12 & 1.291 & 1.291 & 1.291 & 1.292 & 1.294 & 1.295 & 1.296 \\
\hline C11-C13 & 1.501 & 1.501 & 1.501 & 1.501 & 1.505 & 1.503 & 1.504 \\
\hline C13-C14 & 1.337 & 1.337 & 1.337 & 1.337 & 1.337 & 1.340 & 1.338 \\
\hline C13-N16 & 1.434 & 1.434 & 1.434 & 1.434 & 1.436 & 1.435 & 1.436 \\
\hline N16-C17 & 1.302 & 1.302 & 1.302 & 1.302 & 1.306 & 1.302 & 1.305 \\
\hline C17-N18 & 1.436 & 1.436 & 1.436 & 1.436 & 1.419 & 1.431 & 1.424 \\
\hline $\mathrm{C} 19-\mathrm{O} 20$ & 1.439 & 1.439 & 1.440 & 1.440 & 1.438 & 1.439 & 1.439 \\
\hline $\mathrm{C} 21=\mathrm{O}$ & 1.219 & 1.216 & 1.216 & 1.216 & 1.215 & 1.225 & 1.216 \\
\hline $\mathrm{C} 21-\mathrm{O} 22$ & 1.388 & 1.395 & 1.393 & 1.393 & 1.406 & 1.380 & 1.404 \\
\hline O22-R & 0.990 & 1.437 & 1.441 & 1.442 & 1.434 & 1.448 & 1.441 \\
\hline
\end{tabular}




\begin{tabular}{|c|c|c|c|c|}
\hline \multirow{3}{*}{ Bond description } & \multicolumn{4}{|c|}{$-\mathrm{R}$} \\
\hline & $\mathrm{CH}_{3}$ & $\mathrm{CH}_{3}$ & $\mathrm{CH}_{3}$ & $\mathrm{CH}_{3}$ \\
\hline & $-\mathrm{C} H O C O C H\left(\mathrm{CH}_{3}\right)_{2}$ & $-\stackrel{-}{\mathrm{C}} \mathrm{HOCOOCH}\left(\mathrm{CH}_{3}\right)_{2}$ & $-\mathrm{CCH}_{3} \mathrm{OCOCH}\left(\mathrm{CH}_{3}\right)_{2}$ & $-\mathrm{CCH}_{3} \mathrm{OCOOCH}\left(\mathrm{CH}_{3}\right)_{2}$ \\
\hline S1-C2 & 1.803 & 1.804 & 1.820 & 1.806 \\
\hline S1-C6 & 1.803 & 1.803 & 1.822 & 1.805 \\
\hline $\mathrm{C} 2-\mathrm{C} 3$ & 1.535 & 1.534 & 1.487 & 1.535 \\
\hline $\mathrm{C} 3-\mathrm{C} 4$ & 1.329 & 1.327 & 1.351 & 1.329 \\
\hline C3-C19 & 1.537 & 1.537 & 1.510 & 1.531 \\
\hline C4-N5 & 1.441 & 1.439 & 1.425 & 1.428 \\
\hline $\mathrm{C} 4-\mathrm{C} 21$ & 1.529 & 1.527 & 1.504 & 1.535 \\
\hline N5-C6 & 1.485 & 1.486 & 1.514 & 1.479 \\
\hline N5-C7 & 1.449 & 1.450 & 1.480 & 1.443 \\
\hline C6-C8 & 1.570 & 1.572 & 1.568 & 1.573 \\
\hline C8-N9 & 1.455 & 1.455 & 1.463 & 1.464 \\
\hline N9-H & 1.022 & 1.022 & 1.000 & 1.034 \\
\hline $\mathrm{N} 9-\mathrm{C} 10$ & 1.427 & 1.427 & 1.432 & 1.437 \\
\hline $\mathrm{C} 10=\mathrm{O}$ & 1.220 & 1.220 & 1.216 & 1.219 \\
\hline $\mathrm{C} 10-\mathrm{C} 11$ & 1.536 & 1.536 & 1.509 & 1.547 \\
\hline C11-N12 & 1.291 & 1.291 & 1.295 & 1.291 \\
\hline $\mathrm{C} 11-\mathrm{C} 13$ & 1.501 & 1.501 & 1.467 & 1.497 \\
\hline C13-C14 & 1.337 & 1.337 & 1.370 & 1.338 \\
\hline C13-N16 & 1.434 & 1.434 & 1.410 & 1.433 \\
\hline N16-C17 & 1.302 & 1.302 & 1.341 & 1.302 \\
\hline C17-N18 & 1.436 & 1.436 & 1.409 & 1.434 \\
\hline $\mathrm{C} 19-\mathrm{O} 20$ & 1.439 & 1.439 & 1.413 & 1.440 \\
\hline $\mathrm{C} 21=\mathrm{O}$ & 1.218 & 1.218 & 1.212 & 1.219 \\
\hline $\mathrm{C} 21-\mathrm{O} 22$ & 1.393 & 1.391 & 1.362 & 1.409 \\
\hline $\mathrm{O} 22-\mathrm{R}$ & 1.440 & 1.441 & 1.443 & 1.441 \\
\hline
\end{tabular}

of increasing in bond length on going from Pro. D1 $\left(1^{\circ}\right)$ to Pro. D3 $\left(1^{\circ}\right)$ due to increasing the inductive effect of $\left(-\mathrm{CH}_{2}\right)$ groups. The same reason was found $\left(-\mathrm{CH}_{3}\right)$ for increasing in the O-R bond length of secondary Pro. D10 $\left(2^{\circ}\right)$ than primary Pro. D9 $\left(1^{\circ}\right)$. Generally the $\mathrm{O}-\mathrm{H}$ bond length of the acidic cefpodoxime $(0.990 \AA)$ is shorter than all of the O-R bonds length of the prodrug derivatives, so it is expected to have the largest breaking energy for cracking purpose. Table-1 shows the calculation of the (bond lengths $\AA$ ) for the cefpodoximic acid $(\mathrm{R}=-\mathrm{H})$ and cefpodoximate derivatives Pro. D (1-10) at the equilibrium geometry using UHF method.

Examination of geometrical optimization structures for Pro. D (1-10): Pro. D $(1,2,3)$ possess the higher heat of formation, higher total energy, in the order of Pro. $\mathrm{D}(1<2<3)$, dipole moment in the order of Pro. $\mathrm{D}(3>2>1)$ because of the inductive effect of increasing $\mathrm{CH}_{2}$ group. Pro D $(4,5,6)$ possess the lower total energy in the order of Pro. $\mathrm{D}(6<5<4)$, higher dipole moment in the order of Pro. D $(6>4>5)$. Pro D (7-10) possess the mid values of the heat of formation, total energy and dipole moment (Tables 2 and 3). For compa-rison calculated results of the primary $\left(1^{\circ}\right)$ and secondary derivatives $\left(2^{\circ}\right)$, the results of the two isomers derivative 1-fructosyl $4\left(1^{\circ}\right)$ and 3-glycosyl $5\left(2^{\circ}\right)$ show increasing in O-R bond length with decreasing in $\Delta \mathrm{H}_{\mathrm{f}}$, (meaning $5\left(2^{\circ}\right)$ is more stable than $4\left(1^{\circ}\right)$ ). Also there was decreasing in $\mathrm{E}_{\mathrm{LUMO}}$ and $\Delta \mathrm{E}_{\text {номо-Lumo, with increa- }}$ sing in dipole moment $(\mu)$. It can be seen that cefpodoxime derivatives including (-OCOO) group $\left[8\left(1^{\circ}\right)\right.$ and $\left.10\left(2^{\circ}\right)\right]$ have a shorter $\mathrm{O}-\mathrm{R}$ bond length, lower $\Delta \mathrm{H}_{\mathrm{f}}^{0}$ and larger dipole moment in comparison with the corresponding derivatives $\left[7\left(1^{\circ}\right)\right.$ and $9\left(2^{\circ}\right)$ ] including (OCO) group, so they are expected to be more stable and more viable for using as a carrier-linkage for cefpodoxime drug than others. The physical properties for the minimize structures of cefpodoxime acid and Pro. D (1-10), such as dipole moment, standard heat of formation, $\mathrm{E}_{\text {номо }}, \mathrm{E}_{\mathrm{Lumo}}$ and $\Delta \mathrm{E}_{\text {номо-Luмо }}$ at their equilibrium geometries as calculated by (UHF/STO-3G) method are illustrated in Table-2.

Results for calculations of $O-R$ bond breakage energy: The activation energy in the cefpodoximic acid and Pro. D (1-10) were calculated by using reaction coordinate method [19]. Only $\mathrm{O}_{17}-\mathrm{R}_{19}$ bond length is constrained for the appropriate degree of freedom while all other bonds length are freely optimized. The activation energy values for the O-R rupture reactions were calculated from the difference in energies of the global optimize structures and the derived transition states $\left(\mathrm{E}_{\mathrm{a}}^{\#}=\right.$ $E_{\text {transition state }}-E_{\text {reactant }}$ ). Only one negative frequency was found in the transition state structures. The activation energies obtained from Unrestricted Hartree Fock (UHF/STO-3G) level of theory for cefpodoximic acid and Pro. D (1-10) were calculated without the inclusion of any solvent. In a former studies, it was shown that the UHF/STO-3G yields for the O-R bond rupture reaction path a sudden decline in the total molecular energy calculated after the transition state (t.s) [11-13]. It was important to inspect the shape of the reaction curve for the different prodrugs. The treatment should show the change in molecular energy of the prodrug along the reaction path and the structure of the transition states as well as the end products. The distance between $\mathrm{C}_{17}$ and $\mathrm{O}_{19}$ increases during the cracking purposes. The calculated reaction path of cracking processes 


\begin{tabular}{|c|c|c|c|c|c|c|}
\hline \multirow[b]{2}{*}{$\begin{array}{c}\text { Cefpo } \\
\text { Pro. D No. } \\
\end{array}$} & \multicolumn{6}{|c|}{$\begin{array}{l}\text { TABLE-2 } \\
\text { UHF CALCULATIONS FOR SOME PHYSICAL PROPERTIES OF THE CEFPODOXIMIC } \\
\text { DERIVATIVES AND CEFPODOXIMIC ACID AT THE OPTIMIZE GEOMETRY }\end{array}$} \\
\hline & $-\mathrm{R}$ & $\Delta \mathrm{H}_{\mathrm{f}}^{0}(\mathrm{kcal} / \mathrm{mol})$ & $\mathrm{E}_{\text {номо }}(\mathrm{kcal} / \mathrm{mol})$ & $\mathrm{E}_{\text {LUMO }}(\mathrm{kcal} / \mathrm{mol})$ & $\begin{array}{c}\Delta \mathrm{E}_{\text {Hомо-LUмо }} \\
(\mathrm{kcal} / \mathrm{mol})\end{array}$ & $\begin{array}{l}\text { Dipole moment } \\
\text { (Debye) }\end{array}$ \\
\hline & $-\mathrm{H}$ & -91.661 & -6.884 & 5.605 & 1.279 & 2.394 \\
\hline $1\left(1^{0}\right)$ & $-\mathrm{CH}_{3}$ & -85.283 & -6.857 & 5.660 & 1.197 & 3.213 \\
\hline $2\left(1^{0}\right)$ & $-\mathrm{CH}_{2} \mathrm{CH}_{3}$ & -90.254 & -6.884 & 5.632 & 1.252 & 3.250 \\
\hline $3(20)$ & $-\mathrm{CH}_{2} \mathrm{CH}_{2} \mathrm{CH}_{3}$ & -97.741 & -6.884 & 5.632 & 1.252 & 5.337 \\
\hline $4\left(1^{0}\right)$ & & -301.957 & -6.884 & 5.768 & 1.115 & 6.694 \\
\hline $5\left(2^{0}\right)$ & & -301.080 & -6.911 & 5.524 & 1.386 & 5.260 \\
\hline $6\left(1^{0}\right)$ & & -169.411 & -6.803 & 5.660 & 1.142 & 8.924 \\
\hline $7\left(1^{0}\right)$ & $\prod_{-\mathrm{CHOCOCH}\left(\mathrm{CH}_{3}\right)_{2}}$ & -187.298 & -6.884 & 5.605 & 1.278 & 2.429 \\
\hline $8\left(1^{0}\right)$ & $\prod_{-\mathrm{CHOCOOCH}\left(\mathrm{CH}_{3}\right)_{2}}$ & -229.351 & -6.911 & 5.605 & 1.306 & 2.873 \\
\hline $9\left(2^{0}\right)$ & $\left.\right|_{-\mathrm{C}\left(\mathrm{CH}_{3}\right) \mathrm{OCOCH}\left(\mathrm{CH}_{3}\right)_{2}} ^{\mathrm{CH}_{3}}$ & -185.466 & $-6,857$ & 5.632 & 1.224 & 2.369 \\
\hline $10\left(2^{0}\right)$ & $\left.\right|_{\mathrm{C}\left(\mathrm{CH}_{3}\right) \mathrm{OCOOCH}\left(\mathrm{CH}_{3}\right)_{2}}$ & -228.729 & -6.721 & 6.095 & 0.625 & 2.765 \\
\hline
\end{tabular}

TABLE-3

CALCULATIONS OF UHF FOR SOME KINETIC ENERGIES OF THE CEFPODOXIME ACID AND PRO. D (1-10) DERIVATIVES AT THEIR MINIMIZE GEOMETRIES

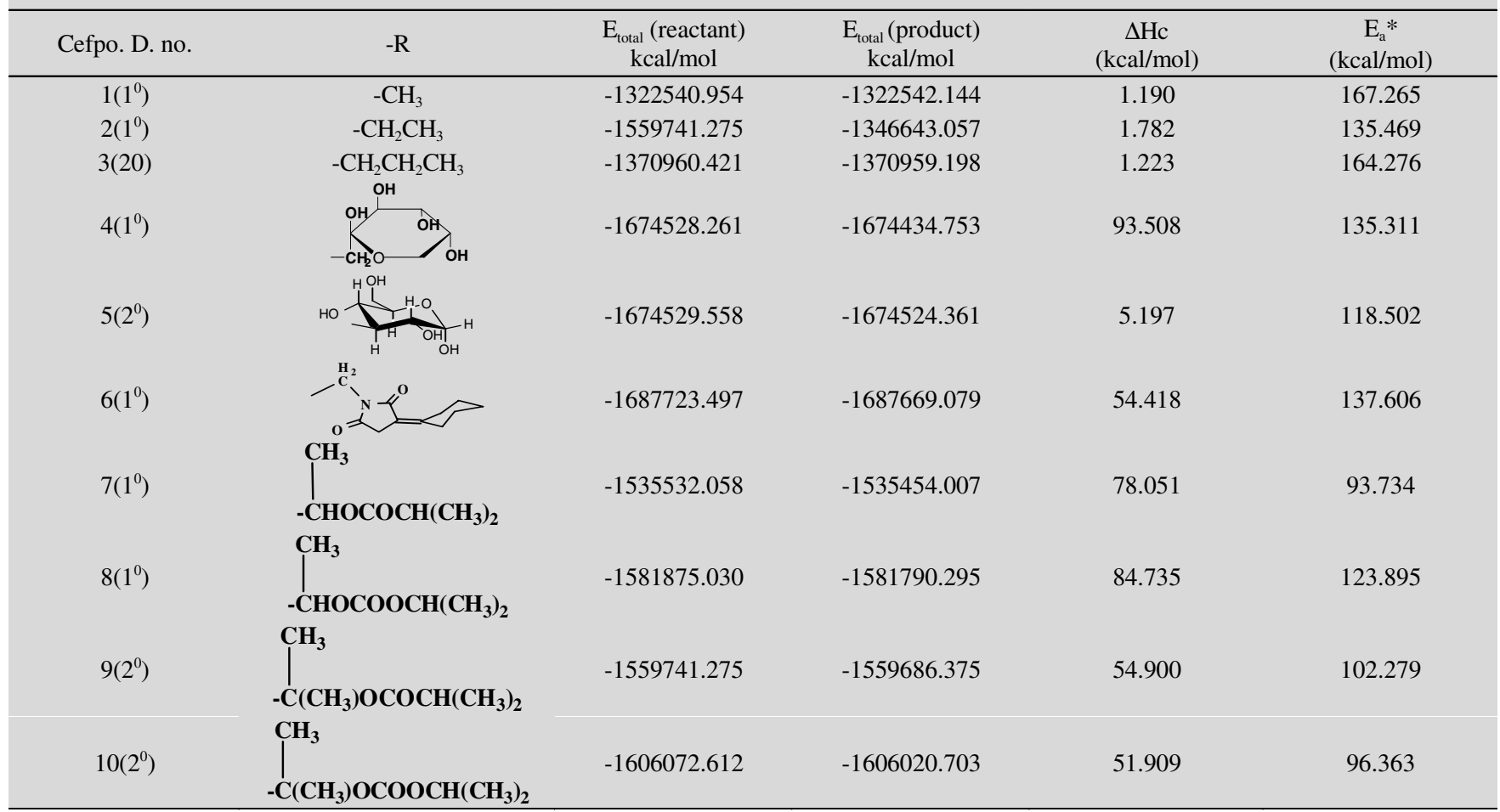

for Pro. D (1-10) was shown in Fig. 2. This figure shows the energy curve for the $\mathrm{O}-\mathrm{R}$ bond rupture of cefpodo-xime ester derivatives calculated by UHF/STO-3G method. There is obvious increase in the dipole moment $(\mu)$ and total energy
$\left(\mathrm{E}_{\mathrm{total}}\right)$ of the molecule with increasing the bond distance of $(\mathrm{O} \cdots \mathrm{R})$ towards transition state (t.s.) [20]. By studying energy curves, it was shown that the O-R bond ruptures reactions of cefpodoxime ester prodrugs of Pro. D (1-3) are reversible, of 


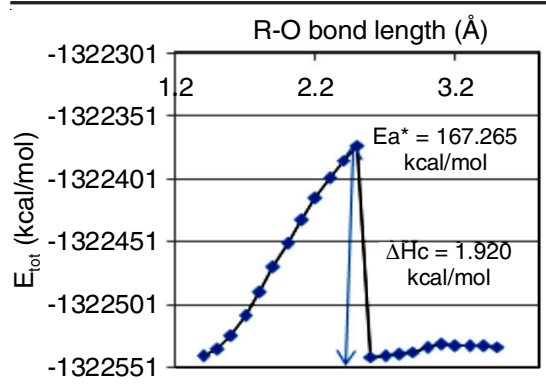

Pro. D1 $\left(\mathrm{R}=\mathrm{CH}_{3}\right)$

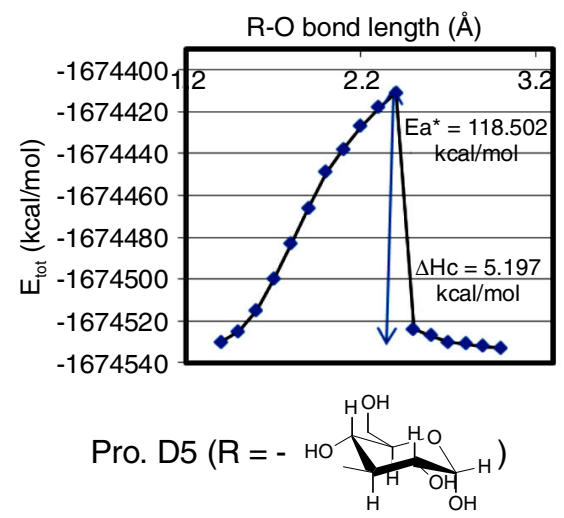

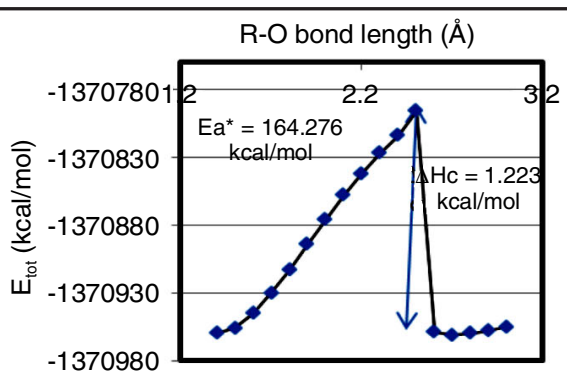

Pro. D3 $\left(\mathrm{R}=-\mathrm{CH}_{2} \mathrm{CH}_{2} \mathrm{CH}_{3}\right)$

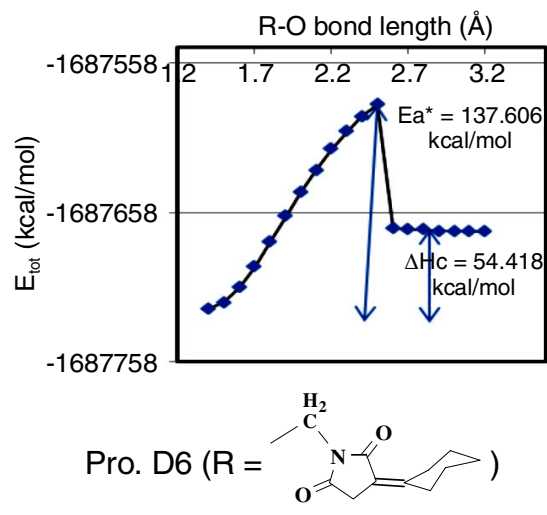

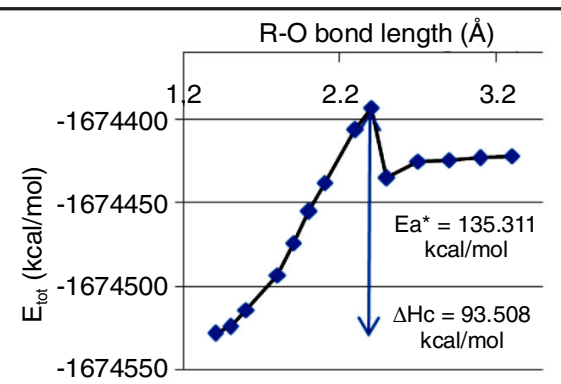

Pro. D4 $\left(\mathrm{R}=-\mathrm{CH}_{-\mathrm{CH}_{2} \mathrm{O}}^{\mathrm{OH}} \stackrel{\mathrm{OH}}{\mathrm{OH}} \underset{\mathrm{OH}}{\mathrm{H}}\right)$

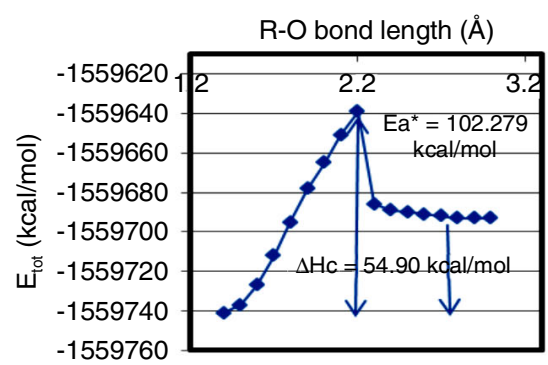

Pro. D7 $\left(\mathrm{R}=-\mathrm{C}\left(\mathrm{CH}_{3}\right)_{2} \mathrm{OCOCH}\left(\mathrm{CH}_{3}\right)_{2}\right)$
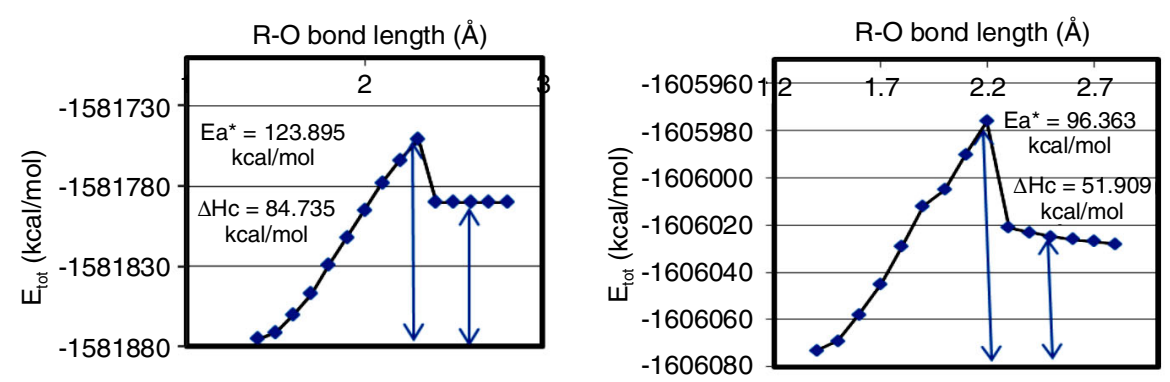

Pro. D10 $\left(\mathrm{R}=-\mathrm{C}\left(\mathrm{CH}_{3}\right)_{2} \mathrm{OCOOCH}\left(\mathrm{CH}_{3}\right)_{2}\right) \quad$ Pro. D8 $\left(\mathrm{R}=-\mathrm{CH}\left(\mathrm{CH}_{3}\right) \mathrm{OCOOCH}\left(\mathrm{CH}_{3}\right)_{2}\right)$

Fig. 2. Calculated reaction path of $\mathrm{O}-\mathrm{R}$ bond breakages reaction for some cefpodoxime prodrugs of different (R) according to $a b$ initio $\mathrm{UHF}$ method

high energy barrier, high activation energy $\left(\mathrm{E}_{\mathrm{a}}^{\#)}\right)$, very low heat of cracking $\left(\Delta \mathrm{H}_{\mathrm{c}}=\mathrm{E}_{\text {(product) }}-\mathrm{E}_{\text {(reactant) }}\right.$, beyond the transition state produces $\sigma$ radical structure and giving free radicals end products. Meaning, sense, these prodrugs do not given cefpodoxime drug as a result of O-R bond breakage as shown in Fig. 3, Table-3. These results correspond to the experimental results in the literature [21].

The end product of the O-R bond ruptures reactions in Pro. D $(4,5)$ given cefpodoxime acid with unstable anion and [2,6-dioxabicyclo[3.2.1]octane-3,4,8-triol] respectively, GMin $(4,5)$. So Pro. D $(4,5)$ do not expected be good prodrugs due to high $\Delta \mathrm{Hc}(93.508 \mathrm{kcal} / \mathrm{mol})$, high activation energy $\mathrm{Ea}^{\#}$ (135.311 kcal/mol) of Pro. D (4) and for very low heat of cracking DHc (5.197 kcal/mol), of Pro. D (5), Table-3, Fig. 4.

The O-R bond ruptures reaction for Pro. D (6) $[R=1$ ethyl-3-methylene-pyrrolidine-2,5-dione] was irreversible, possessing high energy of activation $\mathrm{E}_{\mathrm{a}}^{\#}(137.606 \mathrm{kcal} / \mathrm{mol})$, wasn't showing proton transfer at the transition state and wasn't given cefpodoxime medicine as a final product. Instead, the end product was $[(E)$-(3-cyclohexylidene-2,5-dioxopyrrolidin1-yl)methyl-7-[2-(2-aminothiazol-4-yl)-2-(methoxyimino)acetamido]-3-(methoxymethyl)-8-oxo-5-thia-1-azabicyclo-<smiles>[R]OC(=O)C1=C(COC)CSC2C(NC(=O)/C(=N/OC)c3csc(N)n3)C(=O)N12</smiles><smiles>[R][CH][CH]C1=C(C(=O)[O-])N2C(=O)C(NC(=O)/C(=N/OC)c3csc(N)n3)[C@@H]2SC1</smiles>

\section{$\cdot \mathrm{R}={ }^{\circ} \mathrm{CH}_{3},{ }^{\circ} \mathrm{CH}_{2} \mathrm{CH}_{3},{ }^{\circ} \mathrm{CH}_{2} \mathrm{CH}_{2} \mathrm{CH}_{3}$}

Fig. 3. Products of the calculated O-R bond breakage reaction in cefpodoxime ester prodrugs Pro. D (1-3) 

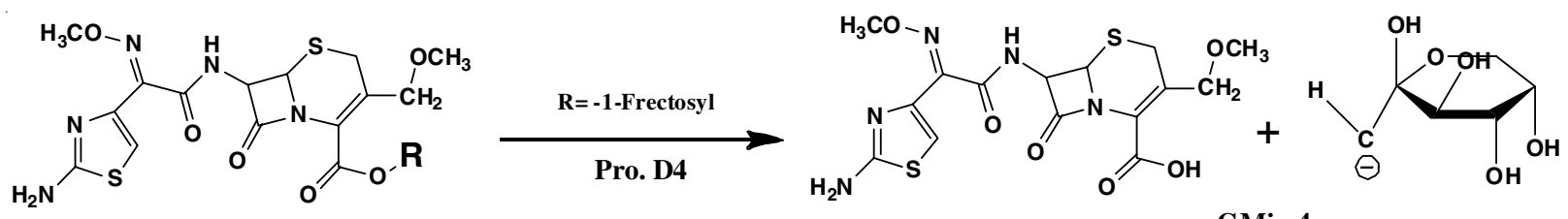

GMin 4

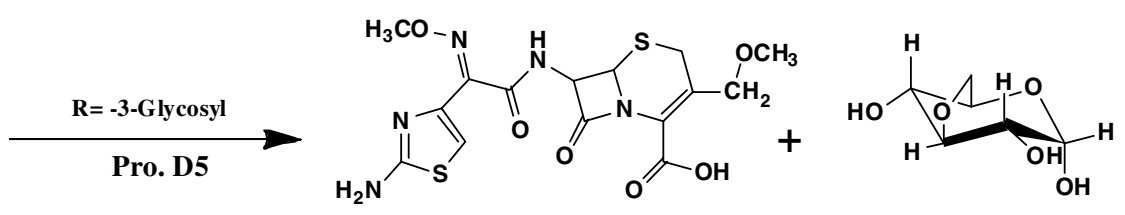

GMin 5

Fig. 4. Products of the calculated O-R bond breakage reaction in cefpodoxime prodrugs (Pro. D4 and Pro. D5)

[4.2.0]oct-2-ene-2-carboxylate] (Fig. 5). So Pro. D (6) is excluded as a good cefpodoxime prodrug and its (R) carrier group is not supported to be good carrier linkage.

The reactions process for O-R bond ruptures of Pro. D $(7,8,9,10)$ were all given cefpodoxime acid with alkenes as a result of O-R bond rupture as shown in Fig. 6, including cefpodoxime proxital (Pro. D8). The calculated values for cefpodoxime proxital were taken as a criterion. In these reactions, the breakage of $\mathrm{O}-\mathrm{R}$ bond was at length of about $1.6 \AA$, leading to form cation and anion fragment. The transition state was at the $\mathrm{O}-\mathrm{R}$ length of (2.2-2.3) $\AA$. Beyond the transition state the $\left(\mathrm{O}_{22}\right)$ anion and the $\mathrm{H}$ proton unite leading to form the end products of cefpodoxime acid and alkenes as a result of the final geometrical minimization, GMin (7-10) [12-14]. The activation energy of the proton transfer is largely depended on the property of the linker carriers [22-25]. The transfer of the proton from the ethyl ester group into the neighboring carboxylic oxygen at the transition state was illustrated in Figs. $7 \mathrm{a}$ and $7 \mathrm{~b}$. Alkenes in acidic media are supposed to turn into acid and alcohol (Fig. 7c).

\section{Conclusion}

In this research, Unrestricted Hartree Fock (UHF) quantum mechanical method was used to confirm the possibility of using theoretical calculations as an initial estimation for different organic groups to be used as carriers for the pharmaceutical compound (cefpodoxime proxital) by calculating the reaction path for the rupture of O-R bond in the pharmacological part. The reaction path, energy of the reactant, transition state, nature and stability of the bond breakage products were studied.

For choosing the organic derivative as a good carrier linkage, it is important to take in account, it is of low dipole moment, the $\mathrm{O}-\mathrm{R}$ bond rupture reaction is irreversible, endothermic (the prodrugs are more stable than their cracking products and not decomposed until reach their side of action). For activation energy it must not too high nor two low for the same reason, the larger values of $\mathrm{E}_{\mathrm{a}}$ \# for prodrugs cracking means possessing unfavourable carrier group (in spite of the stability of the products), the reverse are for the prodrugs possessing favourable carrier group.

These properties were been found in Pro. D (7, 8, 9 and 10) derivatives, so their carriers- linked had the priority to be chosen. The results of the calculation confirmed that there is a good possibility of applying a quantum mechanics account to determine which organic groups can be substituted in drug derivatives as carrier groups of drug related carrier type and applied as treatment drugs.

The theoretical study gave the possibility of specifying the safest and less toxicity groups might be chosen and applied.<smiles>[R]OC(=O)C1=C(COC)CSC2C(NC(=O)/C(=N/OC)c3csc(N)n3)C(=O)N12</smiles>

(Optimization), O-R= 1.441

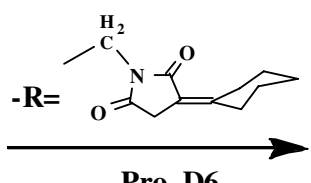

Pro. D6<smiles>COCC1=C(C(=O)[O-])N2C(=O)C(NC(=O)/C(=N/OC)c3csc(N)n3)C2SC1</smiles>

(Transition state), $\mathrm{O}-\mathrm{R}=\mathbf{2 . 2 4 1} \AA$

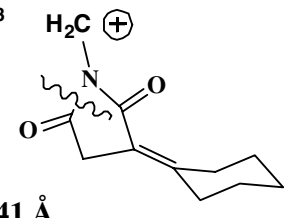<smiles>C=NC(=O)C(CC(=O)OC(=O)C1=C(COC)CSC2C(NC(=O)C(=NOC)c3csc(N)n3)C(=O)N12)=C1CCC(CC)CC1</smiles>

Fig. 5. Products of the calculated O-R bond breakage reaction in Pro. D (6) [R = 1-ethyl-3-methylene-pyrrolidine-2,5-dione]; as a result of $\mathrm{O}-\mathrm{R}$ bond rupture 


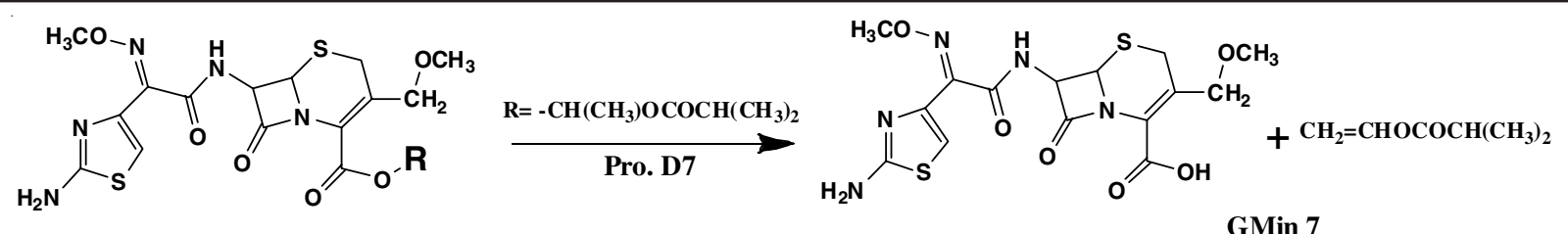

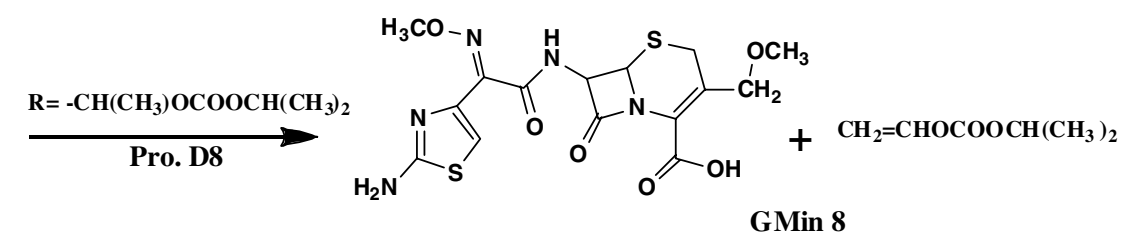

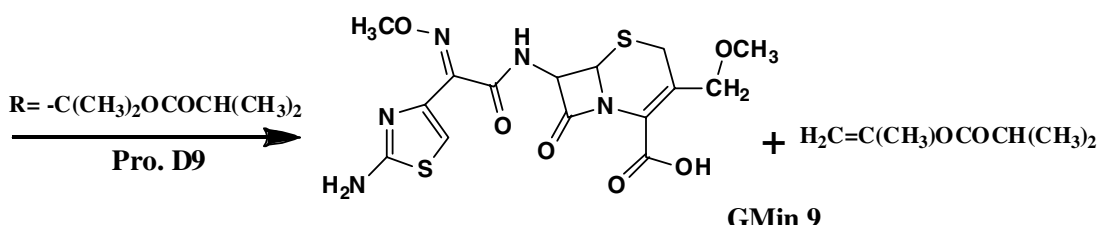

GMin 9<smiles>COCC[C@H]1CC(COC)=C(C(=O)O)N2C[C@@H]1C(NC(=O)c1csc(N)n1)C2=O</smiles>

GMin 10

Fig. 6. End products of O-R bond breakage reaction in cefpodoxime ester prodrugs (giving cefpodoxime acid and alkenes)

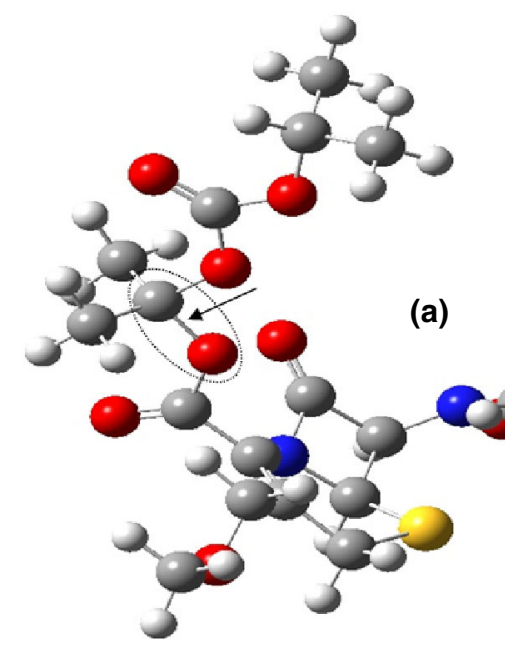

(a)
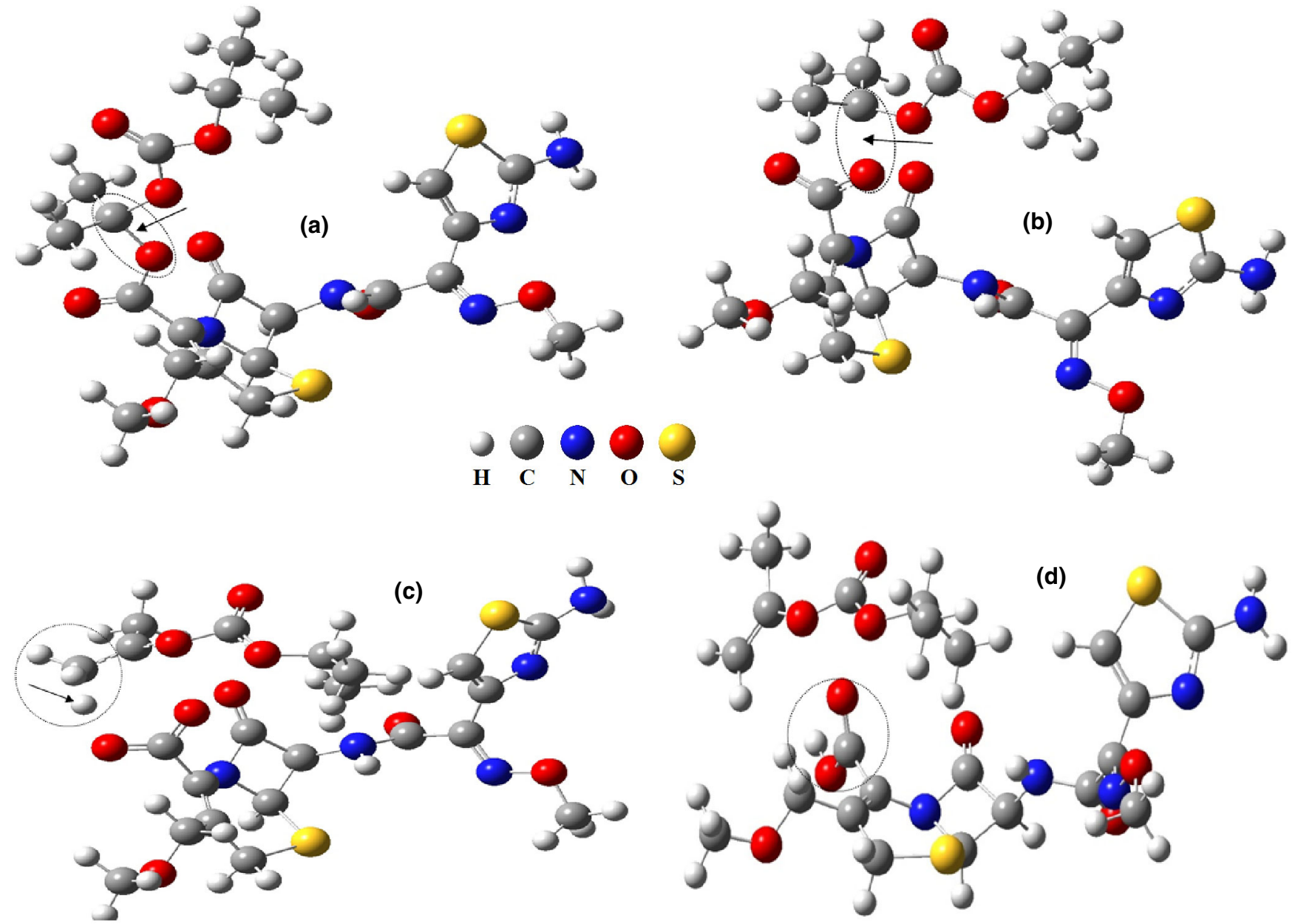

Fig. 7a. Geometrical structure for cefpodoxime proxital at: a) Equilibrium geometry $(\mathrm{O}-\mathrm{R}=1.441 \AA$ ), b) $\mathrm{O}-\mathrm{R}$ breakage bond $(\mathrm{O}-\mathrm{R}=1.541$ $\AA)$, c) Transition state (the proton transfer $(\mathrm{O}-\mathrm{R}=2.341 \AA)$, d) The end product for $\mathrm{O}-\mathrm{R}$ rupture $(\mathrm{O}-\mathrm{R}=2.441 \AA)$ 


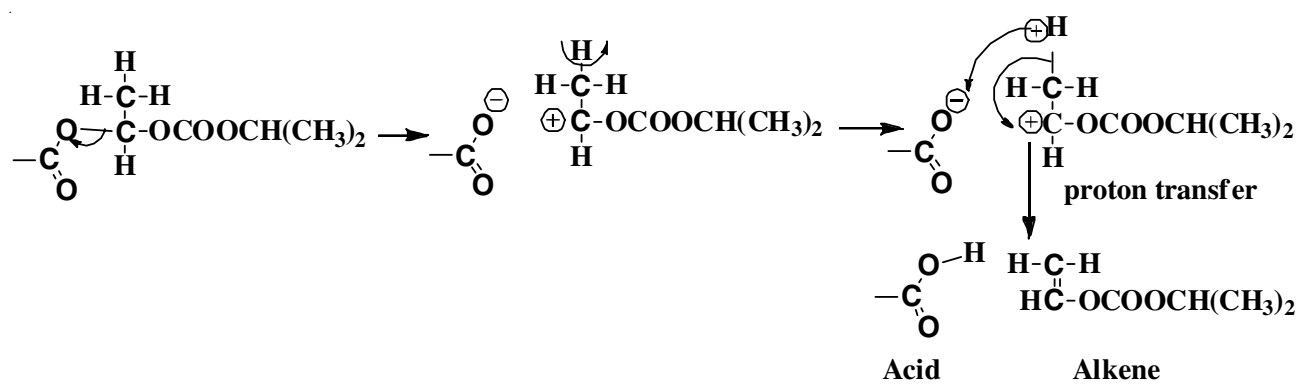

Fig 7b. Mechanism of proton transfer in O-R bond breakage processes in cefpodoxime proxital $\left[\mathrm{R}=-\mathrm{CH}\left(\mathrm{CH}_{3}\right) \mathrm{OCOOCH}\left(\mathrm{CH}_{3}\right)_{2}\right]$

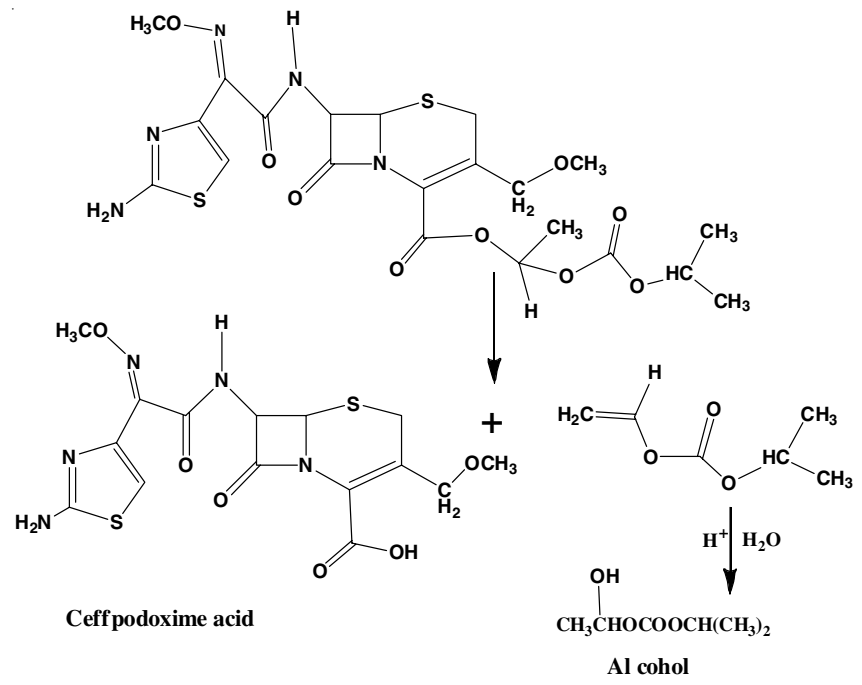

Fig. 7c. Reaction processes of O-R bond breakage in cefpodoxime proxital

\section{REFERENCES}

1. J.O. Neil, Maryadele, The Merck Index, An Encyclopedia of Chemicals, Drugs and Biologicals, Merck Research Laboratories, Division of Merck and Co., Inc. Whitehouse station; New Jersey, edn 14, p. 319 (2006).

2. S.C. Sweetman, Martindale: The Complete Drug Reference, Pharmaceutical Press: London, edn 37, vol. 100(1), pp. 75-76 (2012).

3. C.G. Wermuth, C.R. Ganellin, P. Lindberg and L.A. Mitscher, Pure Appl. Chem., 70, 1129 (1998); https://doi.org/10.1351/pac199870051129.

4. K.D. Tripathi, Essentials of Medical Pharmacology, edn 4, p. 25 (2013).

5. D.L. Mayer, L.N. Jungheim, K.L. Law, S.D. Mikolajczyle and T.A. Shapherd, Cancer Res., 53, 3956 (1993).

6. K.B. Sloan, Prodrug Topical and Ocular Drug Delivery, Dekker: New York, pp 17-22 (1992).

7. S.C. Sweetman, Martindale, The Complete Drug Reference. London: Pharmaceutical Press, edn 35, p. 207 (2007).

8. J. Frau, M. Coll, J. Donoso, F. Munoz and F.G. Blanco, J. Mol. Struct. THEOCHEM, 231, 109 (1991); https://doi.org/10.1016/0166-1280(91)85209-P.

9. R. Karaman, J. Comput. Mol. Des., 24, 961 (2010); https://doi.org/10.1007/s10822-010-9389-6.

10. H. Hejaz, R. Karaman and M. Khamis, J. Mol. Model., 18, 103 (2012); https://doi.org/10.1007/s00894-011-1040-5.
11. R.M. Kubba, Nahrrain Univ. J. Sci. Chem., 15, 1 (2012).

12. R.M. Kubba, and T.M. Al. Mouamin, Anbar J. Pure Sci., 6, 90 (2012).

13. R.M. Kubba and A.A. Sallam, Iraqi J. Sci., 54, 739 (2013).

14. E.G. Lewars, Computational Chemistry: Introduction to the Theory and Applications of Molecular and Quantum Mechanics, Chemistry Department, Trent University Peterborough, Ontario, Canada, edn 2 (2004).

15. M.J. Frisch, G.W. Trucks, H.B. Schlegel, G.E. Scuseria, M.A. Robb, J.R. Cheeseman, G. Scalmani, V. Barone, B. Mennucci, G.A. Petersson, H. Nakatsuji, M. Caricato, X. Li, H. P. Hratchian, A.F. Izmaylov, J. Bloino, G. Zheng, J.L. Sonnenberg, M. Hada, M. Ehara, K. Toyota, R. Fukuda, J. Hasegawa, M. Ishida, T. Nakajima, Y. Honda, O. Kitao, H. Nakai, T. Vreven, J.A. Montgomery Jr., J.E. Peralta, F. Ogliaro, M. Bearpark, J.J. Heyd, E. Brothers, K.N. Kudin, V.N. Staroverov, R. Kobayashi, J. Normand, K. Raghavachari, A. Rendell, J.C. Burant, S.S. Iyengar, J. Tomasi, M. Cossi, N. Rega, J.M. Millam, M. Klene, J.E. Knox, J.B. Cross, V. Bakken, C. Adamo, J. Jaramillo, R. Gomperts, R.E. Stratmann, O. Yazyev, A.J. Austin, R. Cammi, C. Pomelli, J.W. Ochterski, R.L. Martin, K. Morokuma, V.G. Zakrzewski, G.A. Voth, P. Salvador, J.J. Dannenberg, S. Dapprich, A.D. Daniels, Ö. Farkas, J.B. Foresman, J.V. Ortiz, J. Cioslowski and D.J. Fox, Gaussian 09, Gaussian, Inc., Wallingford CT (2009).

16. H. Hejaz, R. Karaman and M. Khamis, J. Mol. Model., 18, 103 (2012); https://doi.org/10.1007/s00894-011-1040-5.

17. S.H. Kazemi, H. Eshtiagh-Hosseini, M. Izadyar and M. Mirzaei, Phys. Chem. Res., 1, 117 (2013).

18. J.N. Murrell and K.J. Laidler, Trans. Faraday Soc., 64, 371 (1968); https://doi.org/10.1039/tf9686400371.

19. K. Muller, Angew. Chem. Int. Ed. Engl., 19, 1 (1980); https://doi.org/10.1002/anie.198000013.

20. M. Shanshal and M.M. Muala, Jordan J. Chem., 8, 113 (2013); https://doi.org/10.12816/0001522.

21. C.O. Wilson, O. Gisvold and R.F. Doerge, Texbook of Organic Medicinal and Pharmaceutical Chemistry, Lippincoot N.Y. Reven, edn 10, p. 258 (1998).

22. S.E. Barber, K.E.S. Dean and A.J. Kirby, Can. J. Chem., 77, 792 (1999); https://doi.org/10.1139/v99-080.

23. A.J. Kirby and N.H. Williams, J. Chem. Soc. Perkin Trans. II, 643 (1994); https://doi.org/10.1039/p29940000643.

24. A.J. Kirby and N.H. Williams, J. Chem. Soc. Chem. Commun., 1643 (1991); https://doi.org/10.1039/c39910001643.

25. E. Hartwell, D.R.W. Hodgson and A.J.J. Kirby, J. Am. Chem. Soc., 122, 9326 (2000); https://doi.org/10.1021/ja002335m. 